\title{
Effect of Bunch Feeding and Bunch Spraying on Fruit Nutrient Status and Cost Economics of Tissue Culture Banana cv. Ney Poovan
}

\author{
B. R. Sathish*, H. S. Yallesh Kumar, M. Ganapathi and M. Narayana Swamy \\ Department of fruit science, College of horticulture, Mudigere, University of Agricultural and \\ Horticultural Sciences, Shivamogga, India \\ *Corresponding author
}

\section{A B S T R A C T}

The present study was conducted during 2017-2018 at College of Horticulture, Mudigere with an objective to know the effect of bunch feeding and bunch spraying on fruit nutrient status and cost economics of tissue culture banana cv. Ney poovan under hill zone of Karnataka. The distal stalk of banana bunch was fed with different nutrient sources like urea, sulphate of potash, banana special and organic formulations like panchagavya and amritpani. The bunch spraying was done thrice with growth regulator 2,4-D at $30 \mathrm{ppm}$ at monthly interval starting from shoot initiation and compared with control (without bunch feeding and bunch spraying). The results revealed that the highest nitrogen $(0.84 \%)$, phosphorous $(0.14 \%)$ and potassium $(0.92 \%)$ content in the fruit was found in $\mathrm{T}_{5}$ (Bunch spray with 2, 4-D $30 \mathrm{ppm}+\mathrm{T}_{2}$-Bunch feeding with Urea $7.5 \mathrm{~g}+\mathrm{SOP} 7.5 \mathrm{~g}$ ) as against control $(0.60 \%, 0.07 \%$ and $0.70 \%$, respectively). Whereas, highest calcium $(0.22 \%)$, magnesium $(0.138 \%)$, sulphur $(0.47 \%)$, zinc $(19.87 \mathrm{ppm})$, boron $(20.32 \mathrm{ppm})$, iron $(124.51 \mathrm{ppm})$ and manganese $(102.46 \mathrm{ppm})$ content in fruits was found in. $\mathrm{T}_{7}$ (Bunch spray with 2, 4-D $30 \mathrm{ppm}+\mathrm{T}_{4}$ - Bunch feeding with SOP $7.5 \mathrm{~g}+$ banana special $0.2 \%$ ). However, lowest calcium $(0.12 \%)$, magnesium $(0.083 \%)$, sulphur $(0.21 \%)$, zinc $(12.23$ $\mathrm{ppm})$, boron $(12.90 \mathrm{ppm})$, iron $(74.28 \mathrm{ppm})$ and manganese $(55.18 \mathrm{ppm})$ content was found in $\mathrm{T}_{1}$ (Control). The economic analysis of the treatments revealed that, treatment $\mathrm{T}_{5}$ (Bunch spray with 2, 4-D $30 \mathrm{ppm}+\mathrm{T}_{2}$-Bunch feeding with Urea $7.5 \mathrm{~g}+$ SOP $7.5 \mathrm{~g}$ ) gave maximum net returns per unit area with a benefit: cost ratio (3.56) when compared to other treatments.

\section{Introduction}

Banana (Musa paradisica L.) belongs to the family Musaceae and genus Musa, a plant genus of extraordinary socio-economic significance to mankind. The name banana comes from the Arabic word 'BANANA', which means finger. It is also known by other synonyms like 'Adam's fig,' 'Kalpataru,' 'Tree of wisdom' and 'Apple of Paradise.' It is one of the oldest fruit crop known to mankind. Banana is the leading fruit crop in tropical and subtropical regions of the world. It ranked second after mango in area and ranked first in productionand grown in more than 132 countries of the world. The fruit is 
recognized as the fourth most important global food commodity in terms of gross value exceeded only by paddy, wheat and maize. It is the staple food of many countries and can be utilized for fodder and fiber too.

Ney Poovan (Elakkibale) is the choicest diploid cultivar, which is under commercial cultivation on a large scale, especially in hill zone of Karnataka. It is medium tall plant takes $12-13$ months to complete its crop cycle. Fruit is highly fragrant, tasty and firm. Among all the cultivars Ney Poovan fetches higher price in the market due to its good keeping quality.

Banana cultivation demands a continuous supply of water and nutrients in large quantities for its growth, development and yield. Potassium and nitrogen arethe essential nutrients for plant growth, development and fruit production. Regardless of cultivars and climate, the total amount of nitrogen taken up by the plant is closely related to total dry matter production (Lahav, 1995), As the banana plant cannot store nitrogen, this nutrient is considered to be in short supply even when the crop was grown on highly fertile soils (Robinson, 1996). Direct application of nutrients to Banana plants through distal stalk end (bunch feeding) and direct spray of nutrients or growth regulators on bunches are important post-shoot bunch management practices to increase the yield and fruit quality. The present study emphasis on influence of bunch feeding and bunch spraying of different nutrients through different sources and growth regulators on fruit nutrient status of banana cultivar 'Ney poovan' ( $A B)$, which helps in accumulation of nutrients in the individual fingers which inturn improves the yield which may in turn help to increase national or state economy and increases confidence in farmers to grow quality produce. Keeping these aspects in view, the present investigation "Effect of bunch feeding and spraying on fruit nutrient status and cost economics of tissue culture banana cv. Ney Poovan (AB) under hill zone of Karnataka" is carried out with an objective to know the effect of bunch feeding and spraying on vegetative and yield attributes of tissue culture banana cv. Ney poovan.

\section{Materials and Methods}

The present investigation was carried out at department of fruit science, College of Horticulture, Mudigere during 2017-18. The principle objective was to study the effect of bunch feeding and bunch spraying on fruit nutrient status and cost economics of tissue culture banana cv. Ney poovan. The land was ploughed twice, harrowed to bring the soil to a fine tilth and leveled. The uniform pits of 60 $\mathrm{cm}^{3}$ were dug out according to the plan of layout and recommended spacing $(2 \mathrm{~m} \times 2 \mathrm{~m})$. All the cultural practices like weeding, desuckering, irrigation and plant protection was taken up in timely interval. For bunch stalk feeding, uniform bunches from each treatment were selected. Rachis at the distal end of the bunch was excised along with male bud giving a slant cut. (De-navelling by excision of rachis $10 \mathrm{~cm}$ after the last hand) Immediately after all the pistillate (female) flowers had set fruits i.e., after four bracts were shed (about 15 days after flower emergence). The prepared $100 \mathrm{ml}$ solution containing $500 \mathrm{~g}$ of fresh cowdung was poured in a thick polythene bag and tied securely by dipping the excised rachis and maintained till harvest.

Bunch spraying was done thrice i.e., first spray at the time of the shooting, the second spray at one month after shooting and third spray at two months after shooting.

The experiment was laid out in a Randomized complete block design (RCBD) with three replications and eight treatments viz., 
$\mathrm{T}_{1^{-}}$(Control -without bunch feeding and bunch spraying),

$\mathrm{T}_{2}$-(Bunch feeding with Urea $7.5 \mathrm{~g}+\mathrm{SOP} 7.5$ g),

$\mathrm{T}_{3^{-}}$(Bunch feeding with Panchagavya 5\% + Amritpani 5\%),

$\mathrm{T}_{4}$-(Bunch feeding with SOP $7.5 \mathrm{~g}+$ Banana special $0.2 \%$ ),

$\mathrm{T}_{5^{-}}$(Bunch spray with 2, 4-D 30ppm $+\mathrm{T}_{2^{-}}$ Bunch feeding with Urea $7.5 \mathrm{~g}+$ SOP $7.5 \mathrm{~g}$ ),

$\mathrm{T}_{6}$-(Bunch spray with 2,4-D 30ppm $+\mathrm{T}_{3^{-}}$ Bunch feeding with Panchagavya 5\% + Amritpani 5\%),

$\mathrm{T}_{7}$-(Bunch spray with 2, 4-D 30ppm $+\mathrm{T}_{4}$ bunch feeding with SOP $7.5 \mathrm{~g}+$ Banana special $0.2 \%$ ) and $\mathrm{T}_{8}-($ Bunch spray with $2,4-$ D 30ppm)

\section{Fruit sample analysis}

Fruit samples were collected from all the treatment plants in each replication after harvest. Later, samples were oven dried at 50 ${ }^{0} \mathrm{C}$ and analyzed for $\mathrm{N}, \mathrm{P} \mathrm{K}, \mathrm{Ca}, \mathrm{Mg}, \mathrm{S}$ and micro nutrients (Jackson, 1973).

\section{Estimation of total Nitrogen}

Total Nitrogen in the plant sample was estimated by micro kjeldahl's method and the samples were digested with concentrated sulphuric acid and digestion mixture in a digestion chamber till a light bluish green residue was obtained. After complete distillation disconnect the receiving flask and then content was titrated against standard sulphuric acid till the colour changed from green to wine red colour (Jackson, 1973). Then per cent total $\mathrm{N}$ was calculated by using formula

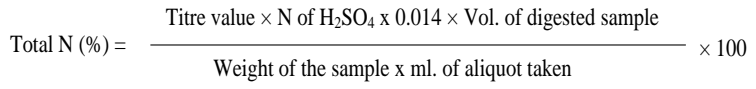

\section{Estimation of Phosphorous}

The phosphorous concentration in the digested solution was determined by transferring $5 \mathrm{ml}$ of the digested aliquot to a volumetric flask, added with $5 \mathrm{ml} \mathrm{HNO}_{3}$ vanadomolybdate reagent and the volume was made up to $50 \mathrm{ml}$. After half an hour, the absorbance was measured at $430 \mathrm{~nm}$ with a visible spectrophotometer. Standard solutions of $\mathrm{KH}_{2} \mathrm{PO}_{4}(50 \mathrm{ppm})$ with a concentration of $0,1.0,2.5,5.0,10,15$ and $20 \mathrm{ppm}$ were prepared by adding the same agent but without plant sample and absorbance was recorded. From the absorbance of standard solutions and unknown sample the graph ppm was calculated. (Jackson, 1967)

$\mathrm{P}(\%)=\frac{\text { Graph ppm } \times \text { Volume of digested sample } \times \text { volume made up }}{10^{6} \times \text { Weight of sample } \times \text { Aliquot taken made up }} \times 100$

\section{Estimation of Potassium}

The potassium concentration in the digested samples was determined by preparing the standard solution of $0,10,20,30,40,80$ and $100 \mathrm{ppm}$ of $\mathrm{K}$ from $100 \mathrm{ppm} \mathrm{KCl}$ and a made up the volume to $50 \mathrm{ml}$ with distilled water. The readings were recorded by feeding the standards in to the flame photometer and the standard curves were prepared by plotting flame photometer reading versus concentrations of standards.

Then the digested samples fed to flame photometer and readings were recorded and compared the unknown sample readings with a standard curve (Jackson, 1973) and graph ppm was recorded.

$$
\mathrm{K}(\%)=\frac{\text { Graph ppm } \times \text { Volume of digested sample }}{10^{6} \times \text { Weight of sample }} \times 100
$$




\section{Estimation of calcium and magnesium}

For estimation of $\mathrm{Ca}+\mathrm{Mg}$, a known aliquot of digested sample $(5-10 \mathrm{ml})$ was taken in a china dish and diluted with distilled water. Then, 5 to $10 \mathrm{ml}$ of buffer solution and few drops of EBT indicator was added and content was titrated against standard EDTA $(0.5 \mathrm{~N})$ solution till the pink colour turned to sky blue colour. From the titre value $\mathrm{Ca}+\mathrm{Mg}$ was calculated. For estimation of calcium alone 10 per cent of $\mathrm{NaOH}$ solution and a pinch of murexide powder was added to a known aliquot $(5-10 \mathrm{ml})$ and the content was titrated against standard EDTA solution till lavender blue colour obtained. The $\mathrm{Mg}$ content was recorded by deducting $\mathrm{Ca}$ values from $\mathrm{Ca}+$ $\mathrm{Mg}$. The per cent calcium and magnesium were calculated by the following formula.

(EBT - Eriochrome Black-T indicator; EDTA - Ethylene Diamine Tetra Acetic Acid)

$\mathrm{Mg}(\%)=\mathrm{Ca}+\mathrm{Mg}(\%)-\mathrm{Ca}(\%)$

\section{Estimation of Sulphur}

The available sulphur was extracted from plant sample by using sodium acetate and acetic acid buffer solution and the aliquot of filtrate solution plus barium chloride was fed to calibrated spectrophotometer and obtained OD values using standard graph was prepared $0,10,20,30$ and $40 \mathrm{ppm}$ of $\mathrm{S}$ standard solution drawn from $100 \mathrm{ppm}$ of $\mathrm{K}_{2} \mathrm{SO}_{4}$ standard solution (Black, 1965).

$$
\text { Available S }(\mathrm{ppm})=\text { Graph ppm } \frac{\text { Vol. of extractant } \times \text { Vol. made up }}{10^{6} \times \text { Wt. of soil Aliquot taken }}
$$

\section{Estimation of micronutrients}

Micronutrients were estimated by directly feeding the filtered Di or tri acid extract of the plant sample to a calibrated atomic absorption spectrophotometer using respective hollow cathode lamps for each element (Fe, Zn, Mn, $\mathrm{Cu}$ ). Micronutrient concentration was expressed in parts per million (ppm) on a dry weight basis (Lindsay and Norvell., 1978).

Micro nutrients $(\mathrm{ppm})=\frac{\text { Sample reading }(\text { graph } \mathrm{ppm})}{\text { Weight of sample }}$

\section{Cost economics}

The benefit-cost ratio for the different treatments was worked out based on the expenditure and returns in order to study the economics of banana production.

\section{Results and Discussion}

\section{Effect of bunch feeding and spraying on nutrient status of fruit}

The data pertaining to the effect of bunch feeding and spraying on nutrient status in banana fruits is presented in table 1.and table 2. The data revealed significant differences among the treatments for all the nutrients studied.

\section{Primary nutrients (N, P and K)}

\section{Nitrogen content of fruits (\%)}

The highest nitrogen content $(0.84 \%)$ was observed in $\mathrm{T}_{5}$ (Bunch spray with 2, 4-D 30 $\mathrm{ppm}+\mathrm{T}_{2}$-Bunch feeding with Urea $7.5 \mathrm{~g}+$ SOP $7.5 \mathrm{~g}$ ) followed by, $\mathrm{T}_{2}$ (Bunch feeding with Urea $7.5 \mathrm{~g}+$ SOP $7.5 \mathrm{~g}(0.82 \%), \mathrm{T}_{7}$ $(0.76 \%)$ and $\mathrm{T}_{4}(0.76 \%)$ Whereas, lowest nitrogen content $(0.60 \%)$ was observed in control $\left(\mathrm{T}_{1}\right)$.

\section{Phosphorous content of fruits (\%)}

The highest phosphorous content $(0.15 \%)$ was observed in $\mathrm{T}_{7}$ (Bunch spray with 2, 4-D 30 $\mathrm{ppm}+\mathrm{T}_{4}$ - Bunch feeding with SOP $7.5 \mathrm{~g}+$ banana special $0.2 \%$ ), which was on par 
(0.14) with $\mathrm{T}_{5}$ (Bunch spray with 2, 4-D 30 $\mathrm{ppm}+\mathrm{T}_{2}$-Bunch feeding with Urea $7.5 \mathrm{~g}+$ SOP $7.5 \mathrm{~g})$. Whereas, lowest phosphorous content $(0.07)$ was observed in control $\left(T_{1}\right)$.

\section{Potassium content of fruits (\%)}

The maximum potassium content $(0.92 \%)$ was observed in $\mathrm{T}_{5}$ (Bunch spray with 2, 4-D $30 \mathrm{ppm}+\mathrm{T}_{2}$-Bunch feeding with Urea $7.5 \mathrm{~g}+$ $7.5 \mathrm{~g} \mathrm{SOP} 7.5 \mathrm{~g}$ ) followed by $\mathrm{T}_{7}$ (Bunch spray with 2, 4-D $30 \mathrm{ppm}+\mathrm{T}_{4}$ - Bunch feeding with SOP $7.5 \mathrm{~g}+$ banana special $0.2 \%)(0.90 \%)$, $\mathrm{T}_{4}(0.88 \%)$ and $\mathrm{T}_{2}(0.87 \%)$ Whereas, lowest potassium content $(0.70 \%)$ was observed in control $\left(\mathrm{T}_{1}\right)$.

Secondary and micronutrients (Ca, Mg, S and $\mathrm{Zn}, \mathrm{B}, \mathrm{Fe}, \mathrm{Mn}$ )

The data pertaining to effect of bunch feeding and spraying on fruit secondary and micronutrient content of tissue culture banana cv. Ney poovan is presented in table 2

\section{Calcium content of fruits (\%)}

Among the different treatments studied the highest calcium content $(0.22 \%)$ was observed in $\mathrm{T}_{7}$ (Bunch spray with 2, 4-D 30 ppm $+\mathrm{T}_{4}$ - Bunch feeding with SOP $7.5 \mathrm{~g}+$ banana special $0.2 \%$ ), followed by $\mathrm{T}_{4}$ (bunch feeding with SOP $7.5 \mathrm{~g}+$ banana special 0.2 $\%)(0.20 \%), \mathrm{T}_{5}(0.18 \%)$ and $\mathrm{T}_{2}(0.16 \%)$. Whereas, lowest calcium content $(0.12 \%)$ was observed in control $\left(\mathrm{T}_{1}\right)$.

\section{Magnesium content of fruits (\%)}

Among the different treatments the highest magnesium content $(0.138 \%)$ was recorded in $\mathrm{T}_{7}$ (Bunch spray with 2, 4-D $30 \mathrm{ppm}+\mathrm{T}_{4^{-}}$ Bunch feeding with SOP $7.5 \mathrm{~g}+$ banana special $0.2 \%$ ), followed by $\mathrm{T}_{4}$ (bunch feeding with SOP $7.5 \mathrm{~g}+$ banana special $0.2 \%(0.127$ $\%), \mathrm{T}_{5}(0.120 \%)$ and $\mathrm{T}_{2}(0.104)$, Whereas, lowest magnesium content $(0.083 \%)$ was recorded in control $\left(\mathrm{T}_{1}\right)$.

\section{Sulphur content of fruits (\%)}

The highest sulphur content $(0.49 \%)$ of fruits was observed in $\mathrm{T}_{7}$ (Bunch spray with 2, 4-D $30 \mathrm{ppm}+\mathrm{T}_{4}$ - Bunch feeding with SOP $7.5 \mathrm{~g}$ + banana special $0.2 \%$ ), followed by $\mathrm{T}_{4}$ (Bunch feeding with SOP $7.5 \mathrm{~g}+$ banana special $0.2 \%)(0.461 \%), \mathrm{T}_{5}(0.330 \%)$ and $\mathrm{T}_{2}$ $(0.319 \%)$. Whereas, lowest sulphur content $(0.213 \%)$ was observed in control $\left(\mathrm{T}_{1}\right)$.

Table.1 Effect of bunch feeding and spraying on fruit N, P and K content of tissue culture banana $\mathrm{cv}$. Ney poovan

\begin{tabular}{|c|l|c|c|c|}
\hline $\begin{array}{c}\text { Treatment } \\
\text { No. }\end{array}$ & \multicolumn{1}{|c|}{ Treatment details } & N (\%) & P (\%) & K (\%) \\
\hline $\mathbf{T}_{\mathbf{1}}$ & Control & 0.60 & 0.07 & 0.70 \\
\hline $\mathbf{T}_{\mathbf{2}}$ & Bunch feeding with Urea 7.5 g + SOP 7.5 g & 0.82 & 0.14 & 0.87 \\
\hline $\mathbf{T}_{\mathbf{3}}$ & Bunch feeding with Panchagavya 5\% + Amritpani 5\% & 0.72 & 0.12 & 0.76 \\
\hline $\mathbf{T}_{\mathbf{4}}$ & Bunch feeding with SOP 7.5 g + Banana special 0.2\% & 0.76 & 0.12 & 0.88 \\
\hline $\mathbf{T}_{\mathbf{5}}$ & Bunch spray with 2, 4-D 30 ppm + T & 0.84 & 0.14 & 0.92 \\
\hline $\mathbf{T}_{\mathbf{6}}$ & Bunch spray with 2,4-D 30 ppm + T & 0.73 & 0.13 & 0.80 \\
\hline $\mathbf{T}_{\mathbf{7}}$ & Bunch spray with 2, 4-D 30 ppm + T & 0.76 & 0.15 & 0.90 \\
\hline $\mathbf{T}_{\mathbf{8}}$ & Bunch spray with 2, 4-D 30 ppm & 0.63 & 0.11 & 0.73 \\
\hline & S.Em $\mathbf{\pm}$ & 0.011 & 0.006 & 0.020 \\
\hline & C.D @ 5\% & 0.033 & 0.02 & 0.061 \\
\hline
\end{tabular}


Table.2 Effect of bunch feeding and spraying on fruit secondary and micronutrient content of tissue culture banana cv. Ney poovan

\begin{tabular}{|c|c|c|c|c|c|c|c|c|}
\hline $\begin{array}{c}\text { Treatment } \\
\text { No. }\end{array}$ & Treatment details & $\begin{array}{c}\text { Ca } \\
(\%)\end{array}$ & $\begin{array}{l}\mathrm{Mg} \\
(\%)\end{array}$ & $\begin{array}{c}S \\
(\%)\end{array}$ & $\begin{array}{c}\mathbf{Z n} \\
(\mathbf{p p m})\end{array}$ & $\begin{array}{c}\text { B } \\
(\mathbf{p p m})\end{array}$ & $\begin{array}{c}\mathbf{F e} \\
(\mathbf{p p m})\end{array}$ & $\begin{array}{c}\text { Mn } \\
(\mathbf{p p m})\end{array}$ \\
\hline $\mathbf{T}_{1}$ & Control & 0.120 & 0.083 & 0.213 & 12.23 & 12.90 & 74.28 & 55.18 \\
\hline $\mathbf{T}_{2}$ & Bunch feeding with Urea $7.5 \mathrm{~g}+$ SOP $7.5 \mathrm{~g}$ & 0.160 & 0.104 & 0.319 & 13.90 & 14.65 & 95.60 & 67.88 \\
\hline $\mathbf{T}_{\mathbf{3}}$ & Bunch feeding with Panchagavya 5\%+Amritpani 5\% & 0.130 & 0.090 & 0.220 & 10.95 & 12.32 & 85.90 & 68.16 \\
\hline $\mathbf{T}_{4}$ & Bunch feeding with SOP $7.5 \mathrm{~g}+$ Banana special $0.2 \%$ & 0.200 & 0.127 & 0.461 & 18.21 & 18.36 & 120.32 & 95.96 \\
\hline $\mathbf{T}_{5}$ & Bunch spray with 2, 4-D $30 \mathrm{ppm}+\mathrm{T}_{2}$ & 0.180 & 0.120 & 0.330 & 14.00 & 14.95 & 102.73 & 70.16 \\
\hline $\mathbf{T}_{6}$ & Bunch spray with $2,4-\mathrm{D} 30 \mathrm{ppm}+\mathrm{T}_{3}$ & 0.130 & 0.100 & 0.227 & 11.68 & 14.47 & 88.10 & 70.34 \\
\hline $\mathbf{T}_{7}$ & Bunch spray with 2 , 4-D $30 \mathrm{ppm}+\mathrm{T}_{4}$ & 0.220 & 0.138 & 0.478 & 19.87 & 20.32 & 124.51 & 102.46 \\
\hline $\mathbf{T}_{8}$ & Bunch spray with 2, 4-D 30 ppm & 0.130 & 0.090 & 0.264 & 13.80 & 14.36 & 90.32 & 65.89 \\
\hline \multicolumn{2}{|r|}{ S.Em \pm} & 0.006 & 0.005 & 0.018 & 0.62 & 0.66 & 2.59 & 2.44 \\
\hline \multicolumn{2}{|r|}{ C.D@ 5\% } & 0.07 & 0.016 & 0.055 & 1.88 & 2.0 & 7.85 & 7.40 \\
\hline
\end{tabular}

Table.3 Effect of bunch feeding and spraying on cost of production per hectare of tissue culture banana cv. Ney poovan

\begin{tabular}{|c|c|c|c|c|c|}
\hline \multirow{2}{*}{$\begin{array}{l}\text { Treatment } \\
\text { No. }\end{array}$} & \multicolumn{4}{|c|}{ Cost of the treatments (Rs) } & \multirow{2}{*}{$\begin{array}{l}\text { Total cost of cultivation } \\
\text { (Rs) }\end{array}$} \\
\hline & $\begin{array}{l}\text { Chemicals/ } \\
\text { nutrients }\end{array}$ & Labour & Polythene covers & Total & \\
\hline $\mathbf{T}_{1}$ & 0 & 0 & 0 & 0 & $* 269023.50$ \\
\hline $\mathbf{T}_{2}$ & 2737.50 & 2000 & 700 & 5437.50 & 274461.00 \\
\hline $\mathbf{T}_{\mathbf{3}}$ & 625.50 & 2000 & 700 & 3325.00 & 272348.50 \\
\hline $\mathbf{T}_{4}$ & 2750.50 & 2000 & 700 & 5450.00 & 274473.50 \\
\hline $\mathbf{T}_{5}$ & 2846.10 & 2000 & 700 & 5546.10 & 274569.60 \\
\hline $\mathbf{T}_{6}$ & 733.60 & 2000 & 700 & 3433.60 & 272457.10 \\
\hline $\mathbf{T}_{7}$ & 2858.60 & 2000 & 700 & 5558.60 & 274582.10 \\
\hline $\mathbf{T}_{8}$ & 108.60 & 2000 & 700 & 2808.60 & 271832.10 \\
\hline
\end{tabular}


Table.4 Effect of bunch feeding and spraying on cost economics of tissue culture banana cv. Ney poovan

\begin{tabular}{|c|c|c|c|c|c|}
\hline $\begin{array}{c}\text { Treatment } \\
\text { No. }\end{array}$ & $\begin{array}{c}\text { Total cost of cultivation } \\
(\mathbf{R s})\end{array}$ & $\begin{array}{c}\text { Fruit yield } \\
\text { (tons/ha) }\end{array}$ & $\begin{array}{c}\text { Gross income } \\
(\mathbf{R s})\end{array}$ & $\begin{array}{c}\text { Net income } \\
(\text { Rs) }\end{array}$ \\
\hline $\mathbf{T}_{\mathbf{1}}$ & 269023.50 & 26.25 & 656250.00 & 387226.5 \\
\hline $\mathbf{T}_{\mathbf{2}}$ & 274461.00 & 34.50 & 862500.00 & 588039.00 \\
\hline $\mathbf{T}_{\mathbf{3}}$ & 272348.50 & 30.53 & 763333.33 & 490984.80 \\
\hline $\mathbf{T}_{\mathbf{4}}$ & 274473.50 & 34.08 & 852083.33 & 577609.80 \\
\hline $\mathbf{T}_{\mathbf{5}}$ & 274569.60 & 39.08 & 977083.33 & 702513.70 \\
\hline $\mathbf{T}_{\mathbf{6}}$ & 272457.10 & 34.50 & 862500.00 & 590042.90 \\
\hline $\mathbf{T}_{\mathbf{7}}$ & 274582.10 & 37.50 & 937500.00 & 6 \\
\hline $\mathbf{T}_{\mathbf{8}}$ & 271832.10 & 31.17 & 779166.67 & 3.10 \\
\hline
\end{tabular}




\section{Zinc content of fruits (ppm)}

Among the different treatments studied the highest zinc content $(19.87 \mathrm{ppm})$ of fruits was observed in $\mathrm{T}_{7}$ (Bunch spray with 2, 4-D 30 $\mathrm{ppm}+\mathrm{T}_{4}$ - Bunch feeding with SOP $7.5 \mathrm{~g}+$ banana special $0.2 \%$ ), followed by $\mathrm{T}_{4}$ (Bunch feeding with SOP $7.5 \mathrm{~g}+$ banana special 0.2 \%) (18.21 ppm), $\mathrm{T}_{5}(14.00 \mathrm{ppm})$ and $\mathrm{T}_{2}$ (13.90 ppm). Whereas, lowest zinc content (12.23 ppm) was recorded in control $\left(\mathrm{T}_{1}\right)$.

\section{Boron content of fruits (ppm)}

Among the different treatments studied the highest boron content $(20.32 \mathrm{ppm})$ of fruits was observed in $\mathrm{T}_{7}$ (Bunch spray with 2, 4-D $30 \mathrm{ppm}+\mathrm{T}_{4}-$ Bunch feeding with SOP $7.5 \mathrm{~g}$ + banana special $0.2 \%$ ), followed by $\mathrm{T}_{4}$ (Bunch feeding with SOP $7.5 \mathrm{~g}+$ banana special $0.2 \%)(18.36 \mathrm{ppm}), \mathrm{T}_{5}(14.95 \mathrm{ppm})$ and $\mathrm{T}_{2}(14.65 \mathrm{ppm})$. Whereas, lowest boron content (12.90 ppm) was recorded in control $\left(\mathrm{T}_{1}\right)$.

\section{Iron content of fruits (ppm)}

Among the different treatments studied the highest iron content (124.51ppm) of fruits was observed in $\mathrm{T}_{7}$ (Bunch spray with 2, 4-D $30 \mathrm{ppm}+\mathrm{T}_{4}$ - Bunch feeding with SOP $7.5 \mathrm{~g}$ + banana special $0.2 \%$ ), followed by $\mathrm{T}_{4}$ (bunch feeding with SOP $7.5 \mathrm{~g}+$ banana special $0.2 \%)(120.32 \mathrm{ppm}), \mathrm{T}_{5}(102.73 \mathrm{ppm})$ and $\mathrm{T}_{2}(95.60 \mathrm{ppm})$.Whereas, lowest iron content $(74.28 \mathrm{ppm})$ was observed in control $\left(\mathrm{T}_{1}\right)$.

\section{Manganese content of fruits (ppm)}

The highest (102.46 ppm) manganese content of the fruit was recorded in treatment $T_{7}$ (Bunch spray with 2, 4-D $30 \mathrm{ppm}+\mathrm{T}_{4}$ - bunch feeding with SOP $7.5 \mathrm{~g}+$ banana special 0.2 $\%$ ), followed by $\mathrm{T}_{4}$ (Bunch feeding with SOP $7.5 \mathrm{~g}+$ banana special $0.2 \%$ ) (95.96 ppm), $\mathrm{T}_{5}$
(70.16 ppm) and $\mathrm{T}_{2}(67.88 \mathrm{ppm})$. Whereas, lowest iron content $(55.18 \mathrm{ppm})$ was observed in control $\left(\mathrm{T}_{1}\right)$.

The higher amount of nutrients in fruit tissues might be due to increased absorption and translocation of nutrients in available form. The readily available form of nutrients makes them easily available for plant physiological processes like respiration, photosynthesis, translocation, protein synthesis and enhanced enzyme activities as reported by Yadav et al., (2010) and Ghanta and Mitra (1993), similar findings were recorded by Kotur and Murthy (2010) in banana cv. Ney poovan who observed the increase in nutrient composition of the fruits due to distal stalk end feeding with ammonium sulphate $(5 \mathrm{~g})$ and sulphate of potash $(2.5 \mathrm{~g})$ along with $500 \mathrm{~g}$ fresh cow dung which in turn confirms the upward movement of applied nutrients through denavelled distal stalk end.

\section{Effect of bunch feeding and spraying on benefit: cost ratio}

Economic study revealed that higher gross income (Rs. 9,77083.33), higher net income (Rs. 7,02,513.70) and highest B:C ratio (3.56) was observed in $\mathrm{T}_{5}$ (Bunch spray with 2, 4-D $30 \mathrm{ppm}+\mathrm{T}_{2}$-Bunch feeding with Urea $7.5 \mathrm{~g}+$ SOP $7.5 \mathrm{~g}$ )followed by $\mathrm{T}_{7}$ (Bunch spray with 2, 4-D 30ppm $+\mathrm{T}_{4}$ - Bunch feeding with SOP $7.5 \mathrm{~g}+$ banana special $0.2 \%$ ) with gross income (Rs 9,37,500), net income (Rs $6,62,917.90)$ and $\mathrm{B}: \mathrm{C}$ ratio (3.41) which was followed by $\mathrm{T}_{2}$ with gross income (Rs $8,62,500)$, net income (Rs 5,88,039.00) and $\mathrm{B}: \mathrm{C}$ ratio (3.14) (Figure 7). Though the cost of cultivation was higher in these treatments, the $\mathrm{B}: \mathrm{C}$ ratio was significantly more due to higher hand weight and bunch weight which intern results in increase in yield levels when compared control which recorded lowest gross income (Rs. 6,56,250), net income (Rs. $3,87,226.50)$ and $\mathrm{B}: \mathrm{C}$ ratio (2.43) due to 
significantly lesser yield. The increase in B:C ratio due to sulphate of potash and urea may be to increase in yield levels by these nutrients. Even though the cost of sulphate of potash is higher compare to other nutrients but produces significantly higher yields along with urea is a cheaply (Rs 6/kg) available nutrient compared to all other chemicals and this led to less investment on chemicals (Table $3 \& 4$ ).

The present investigation was in close conformity with the following findings of Kumar and Kumar (2007) in which they reported that post-shooting spray of sulphate of potash (SOP) at 1.5 per cent recorded highest benefit-cost ratio in banana cv. Robusta. The maximum benefit-cost ratio was obtained in bunch feeding with 2.0 per cent sulphate of potash was recorded by Sreekant et al., (2014) in cv. Grand naine.

Bunch spray with the 2, 4-D also recorded higher benefit-cost ratio compare to control, it may be due to increasing yield levels by 2,4 $\mathrm{D}$ application further it was used in low concentration led to the less investment on it, similar findings were observed by Bauri et al., (2015) in banana cv. Martaman.

In conclusion the direct application of nutrients to plants through distal stalk end(bunch feeding) and direct spray of nutrients on bunches are important post-shoot bunch management practices to increase the yield. Hence from the results obtained in the present study, it can be concluded that the treatment $\mathrm{T}_{5}$ (Bunch spray with 2, 4-D 30 $\mathrm{ppm}+\mathrm{T}_{2}$-Bunch feeding with Urea 7.5 $\mathrm{g}+$ SOP $7.5 \mathrm{~g}$ ) proved to be best for improving the fruit nutrient status which in turn helps to increase the total yield. The economic analysis of the treatments revealed that, treatment $\mathrm{T}_{5}$ (Bunch spray with 2, 4-D 30 $\mathrm{ppm}+\mathrm{T}_{2}$-Bunch feeding with Urea $7.5 \mathrm{~g}+$ SOP $7.5 \mathrm{~g}$ ) gave maximum net returns per unit area (Rs. 7,025,13.00) with a benefit: cost ratio (3.56) when compared to other treatments.

\section{Acknowledgement}

I am extremely grateful to Mr. Yallesh Kumar, H. S., Assistant Professor, Department of Fruit science, College of Horticulture, Mudigere, University of Agricultural and Horticultural Sciences, Shivamogga. Dr. B. S. Shivakumar, Professor and Head, Department of Fruit Science, $\mathrm{COH}$, Mudigere, Dr. Ganapathi, M., Assistant Professor, Department of Crop Physiology, $\mathrm{COH}$, Mudigere, Dr. NarayanaSwamy, M., Associate Professor and Head, AHRS, Sringeri, Mr. Sridhar, R., Assistant Professor, Department of Fruit science, $\mathrm{COH}$, Hiriyuru, for their immense help, valuable suggestions, constant encouragement and critical comments during the course of this investigation.

\section{References}

Bauri, F. K., Sarkar, S. K. and Uchoi, J., 2015, Bunch management technique for improving yield and quality of Martman (AAB) banana. Plant Archives.,12(2): 875-78

Black, C. A., 1965, Method of soil analysis part II, chemical and microbial properties no. 9 in the series of Agronomy. American Soc. Agron. Inc. Madison, Wisconstin, USA.,10(3): 630645.

Ghanta, P. K. and Mitra, S. K., 1993, Effect of micronutrients on growth, flowering, leaf nutrient content and yield of banana cv. Giant Governor. Crop Res., 6(2): 284-287.

Jackson, M.L., 1967, Soil chemical analysis, Printic Hall of India Pvt. Ltd. New Delhi.

Jackson, M. L., 1973, Soil Chemical analysis, 
Printing Hall of India Pvt. Ltd. New Delhi

Kotur, S. C. and Murthy, K. S, V., 2010, Enhancing fruit yield in 'Ney Poovan' banana (Musa paradisiaca L.) by denavelling and feeding nitrogen, potassium and sulphur through distal stalk-end of the bunch. J. Hortl. Sci., 5(1): 53-56.

Lahav, E., 1975, Effect of potassium level on the content of free amino acids in banana suckers.Agrochimica, 19: 319325.

Lindsay, W. L. and Norvell, W. A., 1978, Development of DTDP soil test for zinc, iron, manganese and copper. Soil
Sci. Soc. Amer. J., 42: 421-428.

Robinson, J. C., 1996, Banana and Plantains, CAB International, Wellingford, U.K.

Sreekant, H. S., Thippesha, D., Akshay, K. R. and Deepak, T. M., 2014, Effect of bunch feeding on yield of Banana $\mathrm{Cv}$. Robusta (Aaa group) under hill zone of Karnataka. Int, j. Trop. Agric., 32: 1-2.

Yadav, H. C., YAdav, A. L., Yadav, D. K. AND Yadav, P. K., 2010, Effect of foliar application of micronutrients and $\mathrm{GA}_{3}$ on fruit yield and quality of rainy season guava (Psidium guajava L.) cv. L-49. Pl. Arc.,11(1): 147-149.

\section{How to cite this article:}

Sathish, B. R., H. S. Yallesh Kumar, M. Ganapathi and Narayana Swamy, M. 2021. Effect of Bunch Feeding and Bunch Spraying on Fruit Nutrient Status and Cost Economics of Tissue Culture Banana cv. Ney Poovan. Int.J.Curr.Microbiol.App.Sci. 10(01): 3565-3574. doi: https://doi.org/10.20546/ijcmas.2021.1001.421 